\section{Nitrogen Supplying Capacity of Brown Forest Soil under Different Cropping Practices and 0.01 $\mathrm{M} \mathrm{CaCl}_{2}$ Soluble Organic Nitrogen}

\author{
János Lazányi ${ }^{1}$ - Jakab Loch ${ }^{2}$ - István Henzsel ${ }^{3}$ \\ University of Debrecen, Centre for Agricultural Sciences, \\ ${ }^{1}$ Faculty of Agricultural Economics and Rural Development, \\ Department of Rural Development and Resource Management, \\ Debrecen \\ ${ }^{2}$ Faculty of Agricultural Sciences, \\ Department of Agricultural Chemistry, Debrecen \\ ${ }^{3}$ Research Centre, Nyíregyháza \\ lazanyi@agr.unideb.hu
}

\section{SUMMARY}

The best known and most remarkable example of continuous production in Hungary is the Westsik's crop rotation experiment, which was established in 1929, and is still in use to study the effects of organic manure treatment, to develop models, and predict the likely effects of different cropping systems on soil properties and crop yields. In this respect, Westsik's crop rotation experiment provides data of immediate value to farmers concerning the applications of green, straw and farmyard manure, as well as data sets for scientific research.

Although commonly ignored, the release of nitrogen by root and green manure crops has a significant impact on soil organic matter turnover. The design of sustainable nitrogen management strategies requires a better understanding of the processes influencing nitrogen supplying capacity, as the effects of soil organic matter on soil productivity and crop yield are still very uncertain and require further research. In the treatments of Westsik's crop rotation experiment, nutrients removed from soil through plant growth and harvesting are replaced either by fertilisers and/or organic manure. Data can be used to study the nitrogen supplying capacity of soil under different cropping systems and its effect on the $0.01 \mathrm{M} \mathrm{CaCl}_{2}$ soluble organic nitrogen content of soil.

The aim of this paper is to present data on the nitrogen supplying capacity of brown forest soil from Westsik's crop rotation experiment and to study its correlation with hundredth molar calcium-chloride soluble organic nitrogen. The main objective is to determine the effects of root and green manure crops on the nitrogen supplying capacity of soil under different cropping systems. The nitrogen supplying capacity was calculated as a difference of plant uptake, organic manure and fertiliser supply.

The $0.01 \mathrm{M} \mathrm{CaCl}_{2}$ soluble organic nitrogen test has proved reliable for determining the nitrogen supplying capacity of soils. Brown forest soils are low in organic matter and in the F-1 fallowrye-potato rotation, the nitrogen supplying capacity was 15.6 $\mathrm{kg} / \mathrm{ha} /$ year. $0.01 \mathrm{M} \mathrm{CaCl}_{2}$ soluble organic nitrogen content was as low as $1.73 \mathrm{mg} / \mathrm{kg}$ soil. Roots and green manure increased the nitrogen supplying capacity of soil by more than 100\%. This increase is caused by lupine, a legumes crop, which is very well adapted to the acidic soil conditions of the Nyírség region, and cultivated as a green or root manure crop to increase soil fertility.

Keywords: cropping practice, nitrogen supplying capacity of soil, $0.01 \mathrm{M} \mathrm{CaCl}_{2}$ soluble organic nitrogen

\section{INTRODUCTION}

Mineralisation of organic matter is an important nitrogen pool in sandy soil where reserves of mineral nitrogen are low. Sandy soils are generally well drained and crops do not profit much from mineral nitrogen reserves, as nitrate leaching is high and $\mathrm{NH}_{4}^{+}$binding capacity is low. Németh et al. (1988) have shown that the organic nitrogen fraction extracted by EUF is a reliable indication of mineralisation during the growing season. According to Németh (1996), mineralisation and microbial immobilisation of nitrogen are related to temperature and nutrient amendment. Houba et al. (1986) found that the amount of nitrogen extracted by $0.01 \mathrm{M}$ $\mathrm{CaCl}_{2}$ and EUF correlate well, but the former requires less labour and can be applied in routine measurements. Organic nitrogen extracted by $0.01 \mathrm{M}$ $\mathrm{CaCl}_{2}$ solution highly correlated with the nitrogen uptake by ryegrass in their experiment (Appel and Mengel, 1990).

Mineral nitrogen represents only about $1 \%$ of total nitrogen in the soil and cycles rapidly. It is permanently supplied by the mineralisation of soil organic matter and occasionally by manure fertilisers and atmospheric deposition and depleted by plant uptake, denitrification leaching and immobilisation by microorganism. The organic fraction obtained by a $0.01 \mathrm{M} \mathrm{CaCl}_{2}$ solution represents about $1 \%$ of total organic nitrogen, but has a major impact on plant nutrition and nitrogen cycling. Recent studies have shown that soluble organic nitrogen varied seasonally between $8-20 \mathrm{~kg} / \mathrm{ha}$ in course sand and $15-30 \mathrm{~kg} / \mathrm{ha}$ in brown forest soil. Minimum value was measured in winter; the maximum value in summer.

Mengel et al. (1999) reported 35-45 kg/ha $0.01 \mathrm{M}$ $\mathrm{CaCl}_{2}$ extractable organic matter. Under continuous arable cropping, Murphy et al. (2000) measured 7-18 $\mathrm{kg} / \mathrm{ha} \mathrm{SON}$ after 8 years of grass lay in the $0-25 \mathrm{~cm}$ soil layer, which accounted for $33-60 \%$ of the total soluble nitrogen. Even higher SON was measured in a soil profile of 0-90 cm after ploughing up grassland from a long-term experiment. Appel and Mengel (1992) found a correlation between SON and nitrogen mineralisation, and suggested that SON extracted by $0.01 \mathrm{M} \mathrm{CaCl}_{2}$ solution is a reliable indicator of organic $\mathrm{N}$ available for mineralisation 
and plant uptake. In a previous paper, data were presented on hundredth molar calcium-chloride soluble organic nitrogen in the soil of a Westsik crop rotation experiment and its effects on potato yield Lazányi et al. (2003).

\section{MATERIAL AND METHODS}

In the sandy soils of the Nyírség region, the process of soil formation could not bring about fundamental changes because of the short time interval and limited extent of the necessary conditions. Sand was deposited by the rivers Bodrog, Latorca, Ung, Tisza, Túr, Szamos and Kraszna and, as a result of its low colloid content and excessive leaching, the upper layer of soil became acidic and its nutrient content decreased considerably. The accumulation horizon of the soil is compact, and frequently also acidic. The water and nutrient management of brown forest soil is better than that of the drifting sand, as the clay content of the soil can store moisture and nutrients. The organic matter content of this soil is also higher.

Despite intensive research, the present state of knowledge on the formation and fate of soil organic matter and its response to organic matter mineralisation in changing environmental conditions is still fragmented and are often inconsistent. The crop rotation experiment offers an excellent possibility to study soil fertility management in many respects. This experiment consists of 15 treatments and enables the study of nitrogen supplying capacity of soil under different applications of green, straw and farmyard manure, and to study the ecological impact as well as the economical aspects of different management methods. One of the main practical objects of the Westsik's crop rotation experiment was to measure the long-term effects of different organic manure and inorganic fertilisers on rye and potato production (Westsik, 1951). Crop rotations are divided into three series, except for one, coded F-8, which has four series. At the beginning, the size of the plot was $2880 \mathrm{~m}^{2}$, but due to the introduction of mechanisation, it was reduced to $2700 \mathrm{~m}^{2}$. The total area of the crop rotation experiment is 12,4 hectares, as all the series in each treatment are sown every year.

The F-1 block received no fertilisers and organic material treatment except the rye and potato roots and straw incorporated into the soil. The fallow in this block was a green one and the plant material produced was ploughed into the soil. The F-2 block represents green manure treatment, where lupin was grown as a main crop and incorporated into the soil 4-5 weeks after flowering. The phosphorus and potassium fertilisers in this treatment were applied the previous autumn before the lupin was sown. The F-3 block represents lupin root manure treatment, where lupin was grown for grain and the total organic material, except for the grain, was incorporated into the soil. Blocks F-4-F-7 represent straw manure treatments. In the F-4 block, the rye straw was applied as mulch. In blocks F-6 and F-7, straw manure was fermented without nitrogen and in block F-6 with nitrogen addition. The straw manure was incorporated into the soil 4-6 weeks before the sowing of rye.

F-8 is the only block with 4 main crops, where lupin grew twice in 4 years; once as a main crop produced for grain, and once as a second crop produced after rye and before potato, for green manure. In the F-9 block, lupin was grown as a forage crop and harvested 2-3 weeks after flowering. Blocks F-10 and F-11 represent farmyard manure treatments without and with supplementary fertilisers respectively. In block F-12, lupin is grown after a green forage crop and sown in May. This block is also evaluated with farmyard manure treatments to measure the comparative effects of the two treatments. Blocks F-13, F-14, F-15 represent green manure treatments, where lupin is grown as a second crop after rye and before potato. The F-15 block received no supplementary fertilisers. The difference between blocks F-13 and F-14 can be found in the time of the incorporation of green manure.

Soil samples were collected in the vegetation period of potato just before flowering, from 9 different places, to study within plot variation. Samples were taken from a subplot of $300 \mathrm{~m}^{2}$ and 6 elementary samples were united to give a representative sample. No elemental samples were collected from the $1 \mathrm{~m}$ strip between the parcels. Samples were taken with a soil drill from depths of 0-20, 20-40, 40-60 cm. Before grinding, soil samples were cleaned of plant remains and other possible contamination, and were stored in paper bags in a dry place until examination. The present experiment was designed to study the spatial distribution of the soil organic nitrogen obtained by $0.01 \mathrm{M} \mathrm{CaCl}_{2}$ solution and mineral forms in the soil of Westsik's crop rotation experiment. Statistical methods applied include paired sample $\mathrm{T}$ tests, general linear model for repeated measures and linear regression of SPSS statistics.

\section{RESULTS AND DISCUSSION}

The mineralisation of organic matter primarily depends on the temperature and organic matter content of the soil, but it can even be influenced by agricultural engineering methods. Under aerobic conditions, the process of ammonification is slow, when compared to the formation of nitrate and nitrite. Thus, the ammonia formed directly turns into nitrite, and then into nitrate. Adequate water supply and 30$35{ }^{\circ} \mathrm{C}$ soil temperature are beneficial for nitrification. In the case of decreased nitrification, ammonia is partly utilised by plants, partly by heterotrophic microorganisms, or it may be absorbed on the surface of clay minerals. Furthermore, under anaerobic conditions, the process comes to equilibrium, and ammonia turns into nitrogen gas in the denitrification process. In the Nyírség region, nitrification is also blocked by soil acidity. The total nitrogen content of the soil in Westsik's crop rotation is between 0.02 and $0.12 \%$, corresponding to a total amount of 0.5 - 
$2.5 \mathrm{t} /$ ha in the upper, cultivated layer. The amount of nitrogen available for plants is much less and influenced by soil organic matter content. Soil contains more nitrogen in its upper $20 \mathrm{~cm}$ thick layer than in the underlying layers, as a large part of the nitrogen derives from organic matter of floral, faunal and microbiological origin.

As we know the yield and nitrogen content of each crop, it is possible to draw up a nutrient balance for the treatment of the Westsik experiment. We determined the nitrogen content of the main crop and that of the by-products. On the basis of laboratory tests and published data, we used the values of nitrogen $26 \mathrm{~kg} / \mathrm{t}$ with rye and $5 \mathrm{~kg} / \mathrm{t}$ with potato to calculate nitrogen uptake in the crop rotation experiment (Table 1). We also know the amount of nitrogen distributed in the form of organic manure and fertiliser (Table 2). Soil nitrogen supplying capacity was calculated as a difference of nitrogen uptake by plants and nitrogen distributed in the form of organic manure and fertiliser. While calculating nitrogen balance, we did not take into consideration the amount of lupin green and root manure returned to the soil and their effects is calculated as a part of soil nitrogen supplying capacity.

Total nitrogen uptake by plants between 1931-2002

\begin{tabular}{|l|l|l|l|r|r|r|r|r|r|}
\hline CR & \multicolumn{1}{|c|}{ S-1 } & \multicolumn{1}{|c|}{ S-2 } & \multicolumn{1}{|c|}{ S-3 } & $\begin{array}{c}\text { S-1 } \\
\mathbf{k g} / \mathbf{h a}\end{array}$ & $\begin{array}{c}\text { S-2 } \\
\mathbf{k g} / \mathbf{h a}\end{array}$ & $\begin{array}{c}\text { S-3 } \\
\mathbf{k g} / \mathbf{h a}\end{array}$ & $\begin{array}{c}\text { S-4 } \\
\mathbf{k g} / \mathbf{h a}\end{array}$ & $\begin{array}{c}\text { Total } \\
\mathbf{k g} / \mathbf{h} / \mathbf{3}-\mathbf{4} \text { years }\end{array}$ \\
\hline F-1 & Fallow & Rye & Potato & & 0.0 & 24.4 & 22.4 & & 46.8 \\
\hline F-2 & Lupine & Rye & Potato & & 0.0 & 63.0 & 44.5 & & 107.5 \\
\hline F-3 & Lupine & Rye & Potato & & 20.4 & 56.2 & 41.5 & & 118.1 \\
\hline F-4 & Rye & Potato & Rye & & 48.8 & 45.4 & 44.3 & & 138.5 \\
\hline F-5 & Rye & Potato & Rye & & 54.4 & 51.7 & 49.6 & & 155.7 \\
\hline F-6 & Rye & Potato & Rye & & 60.7 & 59.9 & 54.9 & & 175.5 \\
\hline F-7 & Rye & Potato & Rye & & 35.5 & 40.1 & 36.1 & & 11.7 \\
\hline F-8 & Lupine & Rye & Potato & Rye & 27.8 & 68.3 & 63.5 & 67.0 & 226.6 \\
\hline F-9 & Lupine & Rye & Potato & & 36.5 & 63.1 & 47.1 & & 146.7 \\
\hline F-10 & Forage & Rye & Potato & & 41.7 & 53.0 & 51.7 & & 146.4 \\
\hline F-11 & Forage & Rye & Potato & & 62.4 & 65.1 & 62.1 & & 189.6 \\
\hline F-12 & Rye & Rye & Potato & & 44.8 & 63.3 & 57.8 & & 165.9 \\
\hline F-13 & Rye & Potato & Rye & & 57.3 & 54.6 & 55.5 & & \\
\hline F-14 & Rye & Potato & Rye & & 56.7 & 52.6 & 57.5 & & 167.3 \\
\hline F-15 & Rye & Potato & Rye & & 34.6 & 39.6 & 31.3 & & 166.8 \\
\hline
\end{tabular}

Input of nitrogen in the treatments of Westsik crop rotation experiment

\begin{tabular}{|c|c|c|c|c|c|c|c|c|c|c|c|c|c|}
\hline \multirow{2}{*}{$\begin{array}{c}\text { Crop rotation } \\
\text { Series } \\
\end{array}$} & \multirow{2}{*}{\begin{tabular}{|c|} 
OM \\
kg/ha/3y
\end{tabular}} & \multicolumn{4}{|c|}{$\begin{array}{c}\text { Fertiliser (kg/ha/year) } \\
1931-51 \\
\end{array}$} & \multicolumn{4}{|c|}{$\begin{array}{c}\text { Fertiliser (kg/ha/year) } \\
1952-72 \\
\end{array}$} & \multicolumn{4}{|c|}{$\begin{array}{c}\text { Fertiliser (kg/ha/year) } \\
1973-02 \\
\end{array}$} \\
\hline & & $\mathbf{I}$ & II & III & IV & $\mathbf{I}$ & II & III & IV & \begin{tabular}{l|l}
$\mathbf{I}$ \\
\end{tabular} & II & III & IV \\
\hline $\mathrm{F}-1$ & & 0 & 0 & 0 & & 0 & 0 & 0 & & 0 & 0 & 0 & \\
\hline $\mathrm{F}-2$ & & 0 & 0 & 0 & & 0 & 0 & 36 & & 0 & 0 & 44 & \\
\hline F-3 & & 0 & 0 & 0 & & 0 & 0 & 36 & & 0 & 0 & 44 & \\
\hline F-4 & 18 & 36 & 36 & 0 & & 54 & 36 & 0 & & 44 & 44 & 0 & \\
\hline F-5 & 18 & 36 & 36 & 0 & & 54 & 36 & 0 & & 63 & 44 & 0 & \\
\hline F-6 & 41 & 36 & 36 & 0 & & 54 & 36 & 0 & & 63 & 44 & 0 & \\
\hline F-7 & 41 & 0 & 0 & 0 & & 0 & 0 & 0 & & 0 & 0 & 0 & \\
\hline $\mathrm{F}-8$ & & 0 & 0 & 0 & & 0 & 36 & 0 & 36 & 0 & 44 & 0 & 44 \\
\hline F-9 & & 0 & 0 & 0 & & 0 & 36 & 36 & & 0 & 44 & 44 & \\
\hline F-10 & 78 & 0 & 0 & 0 & & 0 & 0 & 0 & & 0 & 0 & 0 & \\
\hline F-11 & 78 & 0 & 0 & 0 & & 0 & 0 & 36 & & 0 & 0 & 44 & \\
\hline F-12 & & 0 & 0 & 0 & & 0 & 0 & 36 & & 0 & 0 & 44 & \\
\hline $\mathrm{F}-13$ & & 36 & 0 & 0 & & 36 & 0 & 36 & & 44 & 0 & 44 & \\
\hline F-14 & & 36 & 0 & 0 & & 36 & 0 & 36 & & 44 & 0 & 44 & \\
\hline F-15 & & 0 & 0 & 0 & & 0 & 0 & 0 & & 0 & 0 & 0 & \\
\hline
\end{tabular}

In Westsik's crop rotation experiment, the amount of nitrogen uptake varied between 46.8 $\mathrm{kg} / \mathrm{ha} / 3$ years and $226.6 \mathrm{~kg} / \mathrm{ha} / 4$ years (Table 1 ). The lowest nitrogen uptake was found in crop rotation F1 , and the highest in F-8. In crop rotation F-1, the nitrogen uptake of the plants averaged 15.6 $\mathrm{kg} / \mathrm{ha} /$ years. A large part of this nitrogen originated from deposition and a small proportion from the nitrogen fixation of leguminous weeds and independent microorganisms living in soil. In the lupine green (F-2) and root (F-3) manure treatments, the nitrogen uptake varied between 107.5 and 118.1 
$\mathrm{kg} / \mathrm{ha} / 3$ years, which demonstrates that main crop lupine can return $60-70 \mathrm{~kg} / \mathrm{ha}$ of nitrogen into the soil (Figure 1). This calculation is based on the amount of nitrogen utilised by the following rye and potato in the experiment. The effects of lupine on soil nitrogen supplying capacity were higher in the F-8 treatment, where the total plant uptake was as high as 226.6 $\mathrm{kg} / \mathrm{ha} / 4$ years.

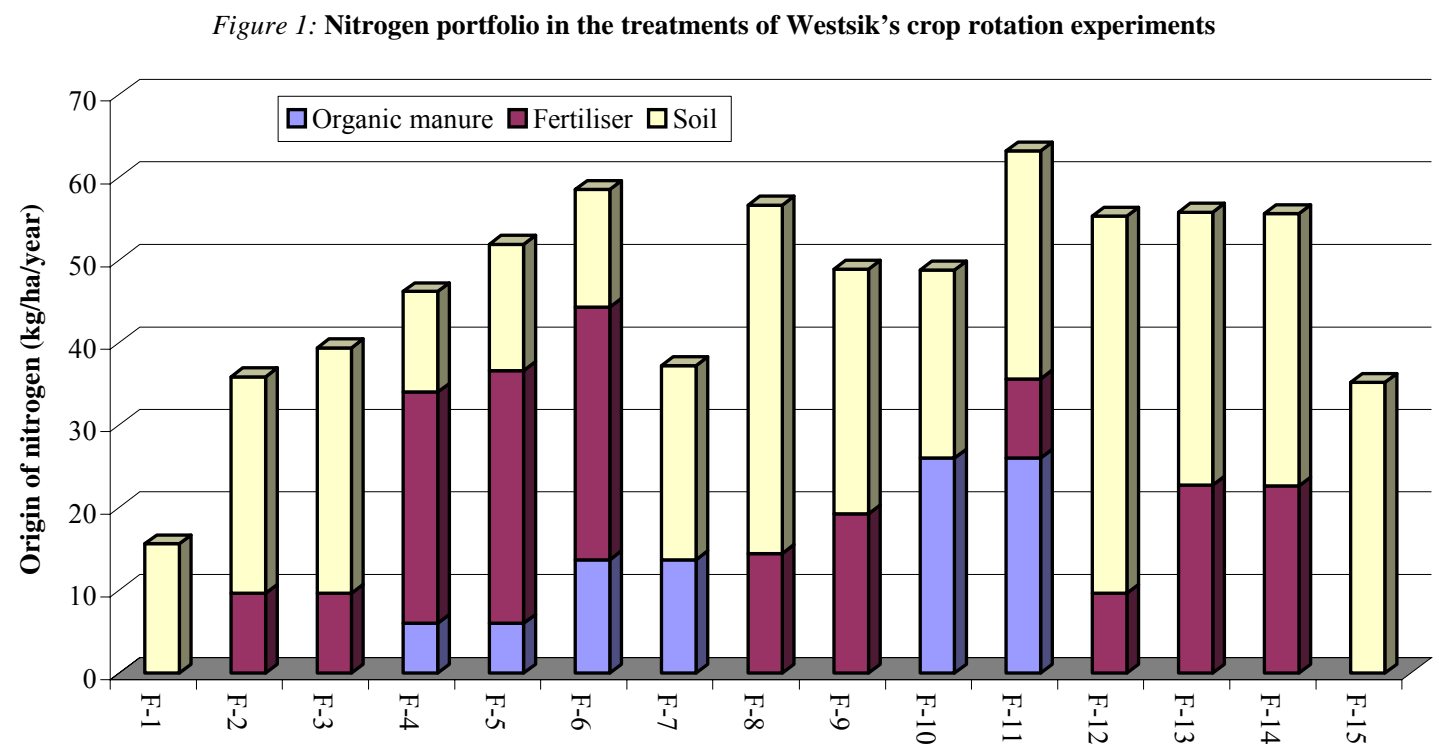

In certain treatments, nitrogen input was in the form of organic manure and/or fertilisers (Table 2). Nitrogen input was calculated $18 \mathrm{~kg} / \mathrm{ha} / 3$ years in F-4 and F-5 for straw, $41 \mathrm{~kg} / \mathrm{ha} / 3$ years in F-6 and F-7 for straw and $78 \mathrm{~kg} / \mathrm{ha} / 3$ years for farmyard manure treatments. There was a slight increase in the dose of nitrogen fertiliser and plant uptake was recalculated for the period of 1931-1951, 1952-1972, 1973-1993, 1994-2002 and 1931-2002 (Table 3).

Nitrogen uptake in treatments of Westsik's crop rotation experiment

\begin{tabular}{|c|c|c|c|c|c|c|c|c|c|c|}
\hline \multirow{2}{*}{ CR } & 1931-1951 & 1952-1972 & 1973-1993 & 1994-2002 & 1931-2002 & 1931-1951 & 1952-1972 & $1973-1993$ & 1994-2002 & 1931-2002 \\
\hline & \multicolumn{5}{|c|}{ Total (kg/ha/3-4 years) } & \multicolumn{5}{|c|}{ Mean (kg/ha/year) } \\
\hline F-1 & 48.2 & 39.5 & 48.6 & 59.5 & 46.8 & 16.1 & 13.2 & 16.2 & 19.8 & 15.6 \\
\hline F-2 & 119.3 & 108.3 & 96.9 & 96.6 & 107.5 & 39.8 & 36.1 & 32.3 & 32.2 & 35.8 \\
\hline F-3 & 120.6 & 107.0 & 117.6 & 133.9 & 118.1 & 40.2 & 35.7 & 39.2 & 44.6 & 39.4 \\
\hline F-4 & 118.9 & 124.4 & 156.3 & 145.3 & 138.5 & 39.6 & 41.5 & 52.1 & 48.4 & 46.2 \\
\hline $\mathrm{F}-5$ & 131.2 & 139.9 & 175.8 & 168.3 & 155.7 & 43.7 & 46.6 & 58.6 & 56.1 & 51.9 \\
\hline F-6 & 150.1 & 154.5 & 202.0 & 191.4 & 175.5 & 50.0 & 51.5 & 67.3 & 63.8 & 58.5 \\
\hline F-7 & 114.3 & 102.2 & 114.7 & 124.1 & 111.7 & 38.1 & 34.1 & 38.2 & 41.4 & 37.2 \\
\hline $\mathrm{F}-8$ & 193.3 & 221.0 & 246.1 & 245.2 & 226.6 & 48.3 & 55.3 & 61.5 & 61.3 & 56.6 \\
\hline F-9 & 106.5 & 123.1 & 132.4 & 155.9 & 146.7 & 35.5 & 41.0 & 44.1 & 52.0 & 48.9 \\
\hline F-10 & 130.1 & 122.6 & 148.8 & 167.9 & 146.4 & 43.4 & 40.9 & 49.6 & 56.0 & 48.8 \\
\hline F-11 & 143.1 & 160.7 & 185.3 & 218.3 & 189.6 & 47.7 & 53.6 & 61.8 & 72.8 & 63.2 \\
\hline $\mathrm{F}-12$ & 164.3 & 155.9 & 157.8 & 169.7 & 165.9 & 54.8 & 52.0 & 52.6 & 56.6 & 55.3 \\
\hline F-13 & 166.4 & 156.3 & 175.0 & 181.8 & 167.3 & 55.5 & 52.1 & 58.3 & 60.6 & 55.8 \\
\hline F-14 & 158.0 & 156.0 & 181.5 & 175.5 & 166.8 & 52.7 & 52.0 & 60.5 & 58.5 & 55.6 \\
\hline F-15 & 129.6 & 107.7 & 89.5 & 78.3 & 105.5 & 43.2 & 35.9 & 29.8 & 26.1 & 35.2 \\
\hline Mean & 132.9 & 131.9 & 148.5 & 154.1 & 144.6 & 44.3 & 44.0 & 49.5 & 51.4 & 48.2 \\
\hline
\end{tabular}

Nitrogen uptake by plants was lowest in the control treatments of Westsik's crop rotation experiments. Total nitrogen uptake in the F-1 treatment was $46.8 \mathrm{~kg} / \mathrm{ha} / 3$ years and in $\mathrm{F}-15$ treatment $105.5 \mathrm{~kg} / \mathrm{ha} / 3$ years. Relatively low nitrogen uptake was found in F-2 and F-3 treatments, were lupine was grown for green and root manure.
The amount of nitrogen gained from lupine green and root manure was higher in the first 21 years of the experiment. This can be explained by the bitter type lupine grown earlier and more careful agricultural practices in the 1930's. Straw manure and increasing nitrogen fertiliser doses have very positive cumulative effects on nitrogen uptake. The tendency 
in total nitrogen uptake was increasing in the F-10 and F-11 treatments and decreasing in the F-15 treatment.

Lupine is traditionally used as green manure in the Nyírség region, but not widely adopted in present day agriculture. The increasing availability of chemical fertilisers and large scale agricultural production have further reduced the use of green manure, although scientists have bred lupine varieties that grow well on unfavourable soils and fix enough atmospheric nitrogen to grow rye or potato in crop rotation. According to Jenkinson and Rayner (1977), forage crops can release an average of 150-200 kg $\mathrm{N} /$ ha/year; far more than the most nitrogen demanding crop could take up. If these crops grow on a well-drained soil, soil cultivation will cause leaching of nitrate down to the soil profile. When soil pores are filled with air, the oxygen demand of the microorganism of the soil is met by the atmosphere and denitrification does not occur. However, if these pores become filled with water, the supply of oxygen to the soil organism is reduced and oxygen deficiency may develop, particularly if the soil is warm and wet, e.g. if nitrate fertilisers are applied before heavy rain in late spring, or in deeper levels of the soil all year round. Only recently, scientists have begun to realise how much fertiliser nitrogen is lost by denitrification, although they have known about the process for more than a century.

Most of the fertiliser nitrogen loss from croplands occurs during late spring and early autumn, through denitrification (Zsolnay, 1996). Except for some heavily fertilised crops, such as oilseed rape, most of the fertiliser nitrogen remaining in the soil at harvest is in organic form, in stable, dead roots and their decomposition product, humus. The main source of the nitrate leached from old arable land is the mineralisation of organic nitrogen in autumn when the soil becomes moistened, temperatures are still relatively high, and the plant demands are low or non-existent. Fertile soils mineralise considerable quantities of nitrogen between harvest and late autumn.

High dose of organic manure can also contribute to the release of nitrogen in autumn. Organic manure acts as slow release fertilisers and releases a major part of its nitrogen in spring and summer, when plants need it, and a certain part in autumn, when it is liable to be leached. The third pathway, i.e. the loss of ammonia to the air, is much less important in croplands, except when a large amount of farmyard manure is used. The main losses of nitrogen in arable farming thus occur via nitrate, either during the autumn and early spring (Johnston, 1987).

Plant uptake was covered by soil nitrogen supplying capacity in F-1, fallow and F-15, lupine second crop green manure treatments, as neither fertiliser nor organic manure, were applied in these treatments, except for the green manure produced in F-15 (Table 4). Plant uptake was covered by straw and farmyard manure in the F-7 and F-10 treatments, where no fertilisers were employed. Soil nitrogen supplying capacity was low in the straw manure treatments ranging from $12.2 \mathrm{~kg} / \mathrm{ha} /$ year in $\mathrm{F}-4$ treatment, where rye straw mulch and nitrogen fertiliser were employed to $23.6 \mathrm{~kg} / \mathrm{ha} /$ year in the F-7 treatment, where fermented straw manure was employed without nitrogen fertilisation. A low soil nitrogen supplying capacity value indicates that one part on nitrogen fertiliser employed in the F-4, F-5 and F-6 treatments was used for the mineralisation of rye straw. The highest soil nitrogen supplying capacity value was calculated in the F-8 treatment, where lupine occurred twice in one cycle: once as a main crop produced for seed, and once as a second crop produced for green manure. A similarly good soil nitrogen supplying capacity value was found in the F-12 treatment, where lupine second crop green manure was sown early June, after harvesting the winter fodder crop.

Soil nitrogen-supplying capacity calculated as a difference of plant uptake, organic manure and fertiliser supply

\begin{tabular}{|c|c|c|c|c|c|c|c|c|c|c|}
\hline \multirow{2}{*}{$\mathbf{C R}$} & 1931-1951 & $1952-1972$ & 1973-1993 & 1994-2002 & 1931-2002 & 1931-1951 & 1952-1972 & 1973-1993 & $1994-2002$ & 1931-2002 \\
\hline & \multicolumn{5}{|c|}{$\begin{array}{c}\text { Total }(\mathrm{kg} / \mathrm{ha} / 3-4 \text { years }) \\
\end{array}$} & \multicolumn{5}{|c|}{ Mean (kg/ha/year) } \\
\hline $\mathrm{F}-1$ & 48.2 & 39.5 & 48.6 & 59.5 & 46.8 & 16.1 & 13.2 & 16.2 & 19.8 & 15.6 \\
\hline F-2 & 119.3 & 72.3 & 52.9 & 52.6 & 78.7 & 39.8 & 24.1 & 17.6 & 17.5 & 26.2 \\
\hline F-3 & 120.6 & 71.0 & 73.6 & 89.9 & 89.3 & 40.2 & 23.7 & 24.5 & 30.0 & 29.8 \\
\hline F-4 & 28.9 & 16.4 & 50.3 & 39.3 & 36.6 & 9.6 & 5.5 & 16.8 & 13.1 & 12.2 \\
\hline F-5 & 41.2 & 31.9 & 50.8 & 43.3 & 45.9 & 13.7 & 10.6 & 16.9 & 14.4 & 15.3 \\
\hline F-6 & 37.1 & 23.5 & 54.0 & 43.4 & 42.7 & 12.4 & 7.8 & 18.0 & 14.5 & 14.2 \\
\hline F-7 & 73.3 & 61.2 & 73.7 & 83.1 & 70.7 & 24.4 & 20.4 & 24.6 & 27.7 & 23.6 \\
\hline F-8 & 193.3 & 149.0 & 158.1 & 157.2 & 168.9 & 48.3 & 37.3 & 39.5 & 39.3 & 42.2 \\
\hline F-9 & 106.5 & 51.1 & 44.4 & 67.9 & 89.0 & 35.5 & 17.0 & 14.8 & 22.6 & 29.7 \\
\hline F-10 & 52.1 & 44.6 & 70.8 & 89.9 & 68.4 & 17.4 & 14.9 & 23.6 & 30.0 & 22.8 \\
\hline F-11 & 65.1 & 46.7 & 63.3 & 96.3 & 82.8 & 21.7 & 15.6 & 21.1 & 32.1 & 27.6 \\
\hline F-12 & 164.3 & 119.9 & 113.8 & 125.7 & 137.1 & 54.8 & 40.0 & 37.9 & $\begin{array}{ll}41.9 \\
\end{array}$ & 45.7 \\
\hline F-13 & 130.4 & 84.3 & 87.0 & 93.8 & 99.2 & 43.5 & 28.1 & 29.0 & 31.3 & 33.1 \\
\hline F-14 & 122.0 & 84.0 & 93.5 & 89.5 & $\begin{array}{l}98.9 \\
\end{array}$ & 40.7 & 28.0 & 31.2 & 29.8 & 33.0 \\
\hline F-15 & 129.6 & 107.7 & 89.5 & 78.3 & 105.5 & 43.2 & 35.9 & 29.8 & 26.1 & 35.2 \\
\hline
\end{tabular}


Westsik's crop rotation experiment assessed the impact of root and green manure crops on the nitrogen supplying capacity of soil. These alternative „fertilisers" can be used as a basis for a sustainable production system. The organic matter content of the soil can be maintained, or even increased, with appropriate organic matter management. Straw manure treatments of Westsik's crop rotation are exemplary in this respect. The amount of organic matter mineralised, and therefore the amount of nitrogen available, is highly dependent on human activity. Due to cultivation, the process of oxidisation becomes more intensive in the soil; the amount of humus content decreases and the nitrogen supply increases.

Less nitrate is lost from the soil of autumn-sown crops than spring-sown ones, because the former takes up at least some of the nitrate found in soil during the autumn. Nitrogen is taken up in the plant over winter, where it is safe from loss. Nitrate remaining in the soil is subject to heavy loss during winter, particularly in sandy soils. Similarly, the earlier a crop is sown in autumn, the more nitrogen it will take up and hold against leaching during the winter. Nitrate leaching can be reduced by avoiding autumn application of nitrogen and by not applying nitrogen too early in the spring. Autumn is a time when there is a surplus of nitrate. Straw absorbs nitrate and later releases this abundance, at a time, when plants are in short supply. Straw incorporation in autumn can reduce leaching of nitrate (Michéli et al., 1993).

Evaluating trends in Figure 2, a high correlation can be demonstrated between nitrogen uptake and $0.01 \mathrm{M} \mathrm{CaCl}_{2}$ soluble organic nitrogen. Based on $0.01 \mathrm{M} \quad \mathrm{CaCl}_{2}$ soluble organic nitrogen measurements, $(\mathrm{x})$ plant nitrogen uptake $(\mathrm{y})$ can be estimated with $\mathrm{y}=7.9193+13.356 \mathrm{x}$ linear equation, where $r^{2}=0.6591$. In the F-2, F-3, F-4, F-9, F-12 and F-14 treatments, nitrogen uptake was higher than expected from $0.01 \mathrm{M} \mathrm{CaCl}_{2}$ soluble organic nitrogen content measurement. While in the F-1, F-5, F-6, F-7 and F-8 treatments, nitrogen uptake was lower than expected when evaluating nitrogen supplying capacity of soil (Figure 2). Previous investigation conducted in Westsik's crop rotation experiment has found a highly significant correlation between organic nitrogen extracted by one-hundredth molar calcium-chloride solution and potato yield Lazányi et al. (2002). It has been shown that soil organic nitrogen extracted by one-hundredth molar calciumchloride solution is a reliable indicator of nitrogen available for mineralisation during the growing season. When precise nitrogen fertiliser recommendations are required, this method can supply additional information for environmentallyfriendly, sustainable agriculture.

Figure 2: Nitrogen uptake and $\mathbf{0 . 0 1} \mathrm{M} \mathrm{CaCl}_{2}$ soluble organic nitrogen

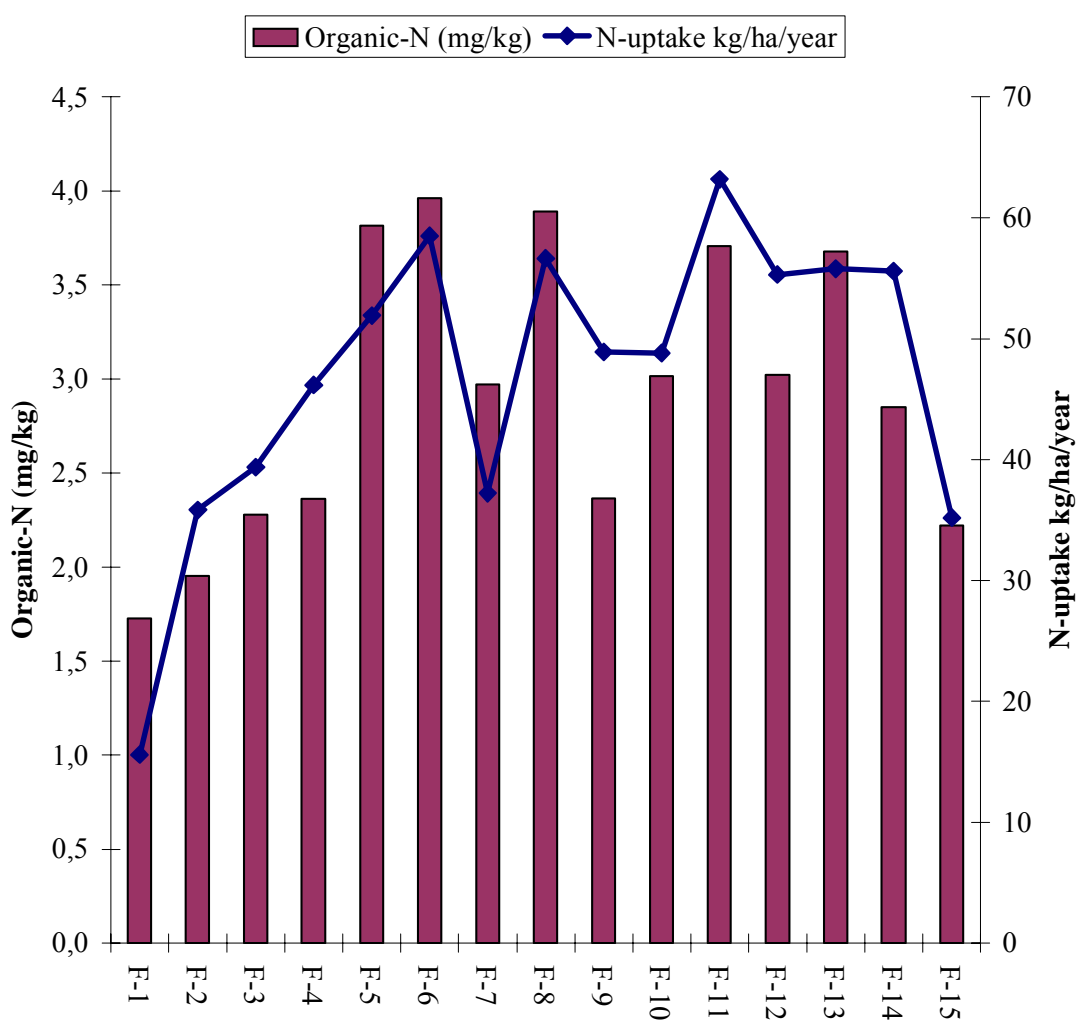

It is in the interests of farmers and water users alike that as little nitrate enters our rivers and aquifers as possible. As the major pathways of loss in arable agriculture are via nitrate, any procedure that keeps nitrate levels low is likely to be beneficial. All the mineral nitrogen added to soils by fixation or 
fertiliser is subject to uptake by roots and microorganisms and to conversion into soil organic matter. The organic matter is reconverted to mineral form by a wide variety of heterotrophic organisms such as bacteria, fungi, and actinomycetes, in a process called mineralisation. These organisms secrete extra cellular enzymes that decompose proteins (Johnston and Poulton, 1980). In many welldrained mineral soils, about $2 \%$ of the organic nitrogen is mineralised annually.

\section{REFERENCES}

Appel, T.-Mengel, K. (1990): Importance of organic nitrogen fractions in sandy soils, obtained by electroultrafiltration or $\mathrm{CaCl}_{2}$ extraction, for nitrogen mineralisation and nitrogen uptake of rape. Biology and Fertility of Soils, 10. 97-101.

Appel, T.-Mengel, K. (1992): Nitrogen uptake of cereals grown on sandy soils as related to nitrogen fertilizers application and soil nitrogen fractions obtained by electro-ultrafiltration (EUF) and $\mathrm{CaCl}_{2}$ extraction. European Journal of Agronomy, 1. 19.

Houba, V. J. G.-Novozamsky, I.-Huybregts, A. W. M.-Van der Lee, J. J. (1986): Comparison of soil extractions by $0.01 \mathrm{M}$ $\mathrm{CaCl}_{2}$ by EUF and by some conventional extraction procedures. Plant Soil, 96. 433-437.

Jenkinson, D. S.-Rayner, J. H. (1977): The turnover of soil organic matter in some of the Rothamsted classical experiments. Soil. Sci., 123. 298-305.

Johnston, A. E. (1987): Effects soil organic matter on yields of crops in longterm experiments at Rothamsted and Woburn. INTECOL Bulletin, 15. 916.

Johnston, A. E.-Poulton, P. R. (1980): Effects of soil organic matter on cereal yields. Rothamsted Experimental Station, Report for 1979, Part 1. 234.

Lazányi, J.-Loch, J.-Jászberényi, I. (2002): Analysis of $0.01 \mathrm{M}$ $\mathrm{CaCl}_{2}$ soluable organic nitrogen in the treatments of Westsik's crop rotation experiment. Agrokémia és talajtan, 51. 1-2. 7989.

Lazányi, J.-Loch, J.-Nagy, P. T. (2003): Importance of 0.01 M
$\mathrm{CaCl}_{2}$ soluble organic nitrogen in the characterisation of $\mathrm{N}$ supply in the treatments of Westsik's crop rotation experiment. In: Schnug, E.-Nagy, J.-Németh, T.-Kovács, Z.Dövényi-Nagy, T. (ed.): Fertilisers in context with recource management in agriculture. 14th International Symposium of Fertilisers, 22-25 June 2003, Debrecen, 104-112.

Mengel, K.-Scheider, B.-Kosegarden, H. (1999): Nitrogen compounds extracted by electroultrafiltration or $\mathrm{CaCl}_{2}$ solution and their relationship to nitrogen mineralisation in soil. J. Plant Nutr. Soil Sci., 162. 139-148.

Michéli, E.-Barabas, E.-Stefanovits, P. (1993): Mineral fertilization and soil organic matter quality. Agrokémia és Talajtan, 42. 90-94.

Murphy, D. V.-MacDonald, A. J.-Stockdale, E. A. (2000): Soluble organic nitrogen in agricultural soils. Biol Fertil Soils, 30. 374-387.

Németh, K.-Bartels, H.-Vogel, M.-Mengel, K. (1988): Organic nitrogen compounds extracted from arable and forest soils by electroultrafiltration and recovery rates of amino acids. Biol Fertil Soils, 5. 537-539.

Németh, T. (1996): Talajaink szervesanyagtartalma és nitrogénforgalma. MTA TAKI, Budapest, 1-382.

Westsik, V. (1951): Homoki vetésforgókkal végzett kísérletek eredményei. Mezőgazdasági Kiadó, Budapest

Zsolnay, A. (1996): dissolved humus in soil waters. In: Piccolo A. (ed.) Humic Substances in Terrestrial Ecosystem. Elsevier, Amsterdam, 171-223. 